\title{
JUGLET PENDANTS FROM PANNONIA
}

\author{
KATA DÉVAI \\ Premium Postdoctoral Program of MTA \\ Eötvös Loránd University \\ Múzeum Krt. 4/B, H-1088 Budapest, Hungary \\ kata.devai@gmail.com
}

\begin{abstract}
Most juglet pendants are of $4^{\text {th }}$ century from Pannonia, the glass is frequently dark, appearing black. Although juglet pendants have a greater concentration in the eastern Mediterranean, they are also widely attested in the empire's western half. The following paper ${ }^{1}$ presents nine specimens from Hungary, eight from Pannonia Province. Three exemplars were parts of grave inventories, whose other items are also known (Bogád, Csongrád and Ságvár). All three burials can be securely dated to the fourth century. Despite the attractiveness of M. Stern's suggestion, there is no good reason to associate the Pannonian juglet pendants recovered from mortuary contexts with Christianity. The pieces from Pannonia would rather suggest that juglet pendants cannot be associated with Christian beliefs because the other grave goods in the burials from which they were recovered belie this association.

Keywords: Roman glass, glass pendant, late Roman burials, Late Roman Pannonia, eulogia
\end{abstract}

Curious little amulets in the shape of miniature juglets are rare finds in Pannonia: no more than a handful are known from this region.

The appearance of this curious type can be dated to the late Roman period. It was principally distributed on the Syro-Palestinian coast, suggesting that its production centre lay in this region, possibly on the southern Levantine coast, its core distribution. Very often, these pendants are recovered from burials. Although juglet pendants have a greater concentration in the eastern Mediterranean, they are also widely attested in the empire's western half.

Most of these pendants were made of opaque glass, with the occasional translucent piece, and they were decorated with coloured trails, usually yellow, white or turquoise. The colour of the juglet itself ranges from dark blue to black. Similarly to glass beads, the choice of colour was probably not mere chance. Blue was most likely chosen because this colour was believed to have magical powers in Antiquity: it was thought that its use would ward off malevolent spirits and provide protection against evil spells. ${ }^{2}$ One reason for the widespread popularity of jewellery types such as finger-rings, bracelets, beads and pendants made in opaque black and dark colours during the Roman Age was that they were regarded as a cheap imitation of jet, a mineral known as "black amber", which was believed to possess magical healing properties. $^{3}$

The juglet pendants are usually quite small, no more than 2-3 cm high. A typological system for these carefully made, pleasing pieces with a distinctive form was set up by E. M. Stern. Regrettably, we still lack a comprehensive survey and assessment of these pendants based on their occurrences. Their basic colour and the colour

${ }^{1}$ Author's note: This paper is part of my research project funded by the Premium postdoctoral fellowship grant of the Hungarian Academy of Sciences (working title: "Glass Vessels in Pannonia: Everyday Usage and Production from the First to Third Centuries
A.D.”; ID number: 462032, host institution: ELTE-Eötvös Loránd University, H-1088 Budapest, Múzeum krt 4/b).

${ }^{2}$ STERn 2001, 361.

${ }^{3}$ Plin., Nat. Hist. 36.34 
of the decorative elements are identical with those of the period's popular beads, and it therefore seems likely that these juglet pendants had been produced in the glass workshops manufacturing glass beads.

The function of these pendants remains elusive and there is no forthcoming answer regarding their use. They could equally well have been worn as simple pendants and as amulets to which magical healing properties were ascribed. Although their form imitates the large glass jugs and pitchers used as part of tableware, they are too small to have been perfume or ointment containers, and it seems more likely that they had been strung on necklaces through their handle. Given that they were hollow, they could have contained some valuable substance (liquids, medicinal herbs and the like). It has been suggested that they had perhaps contained sanctified water, which was obtained by the pilgrims journeying to various renowned sanctuaries. For example, Isis and her cult had a strong association with water and sanctified water played a prominent role in the rituals linked to her worship. ${ }^{4}$ This view has been also advocated by E. M. Stern, even though it yet remains to be proven.

Given that most of these miniature vessels date from the late Roman period, it is possible that their use can be linked to Christianity. The pilgrims visiting the Holy Land acquired them as keepsakes or amulets, which would explain both their concentrations in the East - i.e. that they had quite certainly been produced in the SyroPalestinian region - and their distribution in the West since a few pieces are known from almost every province. Although M. Stern's suggestion on the function of the juglets is highly attractive, there is virtually nothing to confirm this, ${ }^{5}$ and as a matter of fact, the currently available record belies their use in this context. Several juglet pendants have been recovered from burials since the publication of her monograph, whose dating rests on more solid evidence than of the stray pieces in museum collections. Most of these can be assigned to the fourth century or even earlier, both in the case of the Near Eastern and the Pannonian exemplars. In the fourth century, pilgrim eulogia containers were not as widespread as in the fifth and sixth centuries. Juglet pendants are far too early and occur far too frequently in contexts that we have no good reason to regard as Christian for them to be interpreted as Christian eulogia containers. ${ }^{6}$

While this type of function and association is hardly unprecedented, it has been much more clearly documented in the case of the mould-blown hexagonal flasks with Christian and Jewish depictions: these vessels were principally produced in the well-known pilgrimage centres of the East, but they reached the empire's westerly regions through pilgrims. ${ }^{7}$ Discussing the juglet pendants from the Near East, Spaer notes that a definite increase can be noted in the case of three types: the simple drop or jar pendants, the juglet pendants and the disc pendants with stamped motifs. The first type is assigned to the late third and the fourth centuries, the second mainly to the fourth century (with its use extending into the fifth century), while disc pendants to the later fourth and the fifth centuries. ${ }^{8}$ The types were not current simultaneously, although there are overlaps between their usage and, very often, the different types are recovered from the same context. ${ }^{9}$ One unresolved issue is whether the first simple drop or jar pendants had evolved from glass beads; in contrast, juglet pendants expressly imitated glass jugs and pitchers, suggesting that the latter, more sophisticated form had evolved from the former, and that the associated meaning, perhaps religious and magical in nature, was retained.

E. M. Stern distinguished three main types based on form and ornamentation. ${ }^{10}$ From her survey of the findspots of juglet pendants, Stern concluded that their main concentrations are in the Syro-Palestinian region and Rome. ${ }^{11}$

Type I includes the opaque, single-coloured, simple juglets made up of a cylindrical glass rod for the body and glass trails applied in a lattice pattern for creating a globular belly. Type II has a biconical body with a hollow mid-section, with glass trails fused to the vessel body in a spiral or zig-zag pattern. The trails are also opaque, but often of contrasting colours, most often red, yellow, white or blue. Type III has a body resembling a gadrooned melon bead to which two handles were attached. A separate foot-ring was made for the base, while the rim was similarly applied separately. This type was also made from single-coloured glass.

The small juglets were not blown, but were made around glass rods, probably in the workshops producing glass beads and using similar techniques. This would explain why the body of Type III is ultimately the adoption of a bead form. Although these pendants are pleasing, they are simple products rather than artistic pieces; they were

\footnotetext{
${ }^{4}$ WILD 1981.

${ }^{5}$ STERN 2001, 362.

${ }^{6}$ SPAER 1991, 170.

${ }^{7}$ STERN 1995, 137-142.
}

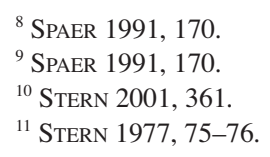


produced in various workshops and therefore they are not uniform in style and neither can any master's hands be distinguished among them. ${ }^{12}$

According to Stern, Type I is principally attested in Galilee, Judea, the Decapolis, Hauran and Homs; Type II is not restricted to Palestine, but appears also in Egypt and the western provinces, and even as far as northwestern Europe. Many pieces are known from Rome; however, most of the western exemplars are single finds, known mainly from the Balkans, Germany, Britain, Spain, Ibiza, Sardinia, the Netherlands and Portugal. ${ }^{13}$ Type III seems to be the earliest, appearing in the later third century, while Types I and II are attested from the mid-fourth century onward..$^{14}$

Although M. Stern's typological classification is wholly acceptable, being ultimately based on the distribution of these finds, her system can be refined by considering a few additional points as well as a finer typological subdivision.

D. Whitehouse published eleven juglet and pitcher amulets, representing a wide typological range. ${ }^{15}$ The diversity of the forms and decorations of these pieces raise several questions regarding their formal classification since these pieces range from simple schematic forms to sophisticated juglets. Their decoration is similarly diverse: aside from single-coloured opaque pieces, some are embellished with marvered trails, openwork cage decoration and glass chips. They include simple shapes made up of a bead to which a disc base and a handle were added, although this type hardly represents genuine jugs. These simple early exemplars can be regarded as the prototypes of the juglet and pitcher amulets, a type also mentioned by Spread, who dates them before the appearance of genuine juglet amulets. ${ }^{16}$ In my view, the variants created from beads should be assigned to a separate category representing the form's prototype. M. Stern's Type III is a juglet amulet created from a bead, specifically from a gadrooned melon bead to which two handles were attached. ${ }^{17}$ Additionally, a classification according to vessel form and the number of handles would also be useful. In terms of their forms, the pendants can be categorised as jars, pitchers or juglets, while the pieces with two handles as amphoras. Within these main forms, sub-types could be distinguished in terms of their decoration: marvered trails, openwork cage or chips.

One of the first pieces known from the empire's western half came to light in Trier among the finds of a workshop producing glass beads, glass jewellery items and pendants with Christian motifs. ${ }^{18}$ Although it was initially assumed that these amulets had been made in the glass workshop, this seems dubious since only a single piece came to light and there is no concentration of juglet amulets in the broader area. No more than a few pieces have been reported, while countless exemplars are known from the Near East. The other larger concentration of finds can be noted in Rome, ${ }^{19}$ where most of these glass amulets were recovered from catacombs, although the exact find contexts remain uncertain. Although it seems likely, their use by Christians cannot be conclusively proven. ${ }^{20} \mathrm{Juglet}$ amulets were found during the excavation of a Christian church at Olympia and countless pieces have been reported from places that were major Christian centres during the fourth century (Nazareth, Gerasa, Samaria, Rome, Trier and Cologne), from which M. Stern concluded that these amulets had been used by Christians. ${ }^{21}$ E. Riha mentions a handful of pieces dating from the fourth century found at Augusta Raurica. The earliest exemplar, dated to the later third century, comes from Castrum Rauracense. ${ }^{22}$ Keller lists four amulets of this type. ${ }^{23}$ Juglet amulets have been found on the following sites in the western empire: Cagliari, Cumae, Callatis, Conimbriga, Celles-sur-Aisne, Cologne, Krefeld-Gellep, Kreunach, Liedena, Maising, Mogosani, Murnau, Olympia, Pompeii, Predjama, Pritzier, Puig d'en Valls, Regensburg, Richborough, Rome, Trier and Zgornij Breg by Ptuj ${ }^{24}$ indicating the occurrence of juglet amulets in Italy, Gaul, Germania, Hispania, Pannonia, Dalmatia and Moesia during the late Roman period. However, only single finds are known from the relevant sites, perhaps an indication that they had reached the western provinces along trade routes leading through the Balkans. The bead type itself was current from the fourth to the seventh century, ${ }^{25}$ not only in the Roman Empire, but also among the German tribes living beyond the empire's

\footnotetext{
${ }^{12}$ STERN 2001, 361.

${ }^{13}$ STERN 2001, 362.

${ }^{14}$ STERN 2001, 362.

${ }^{15}$ Whitehouse 2003, 48-51.

${ }^{16}$ SPAER 1991, 170.

${ }^{17}$ STERN 2001, 361

${ }^{18}$ LOESCHKe 1925, 339
}

\author{
${ }^{19}$ STERN 1971, 112. \\ ${ }^{20}$ STERN 1971, 113. \\ ${ }^{21}$ STERN 1971, 113. \\ ${ }^{22}$ RiHa 1990, 84, Taf. 66, Kat. 2804. \\ ${ }^{23}$ KeLLER 1971, 92, Taf. 328. \\ ${ }^{24}$ SChulze 1978, 66-68. \\ ${ }^{25}$ Whitehouse 2003, 45. \\ Acta Archaeologica Academiae Scientiarum Hungaricae 71, 2020
}




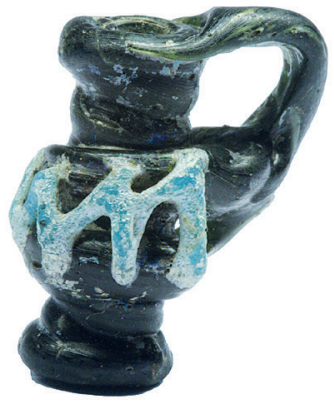

1.

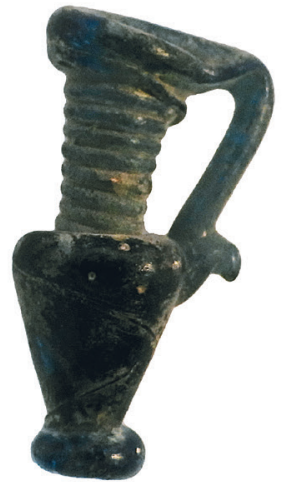

4.

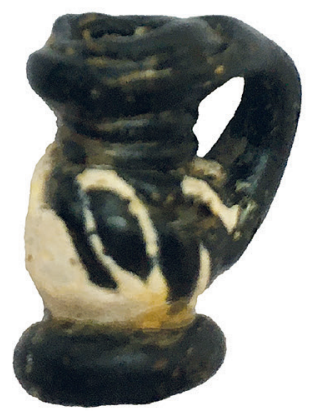

7.

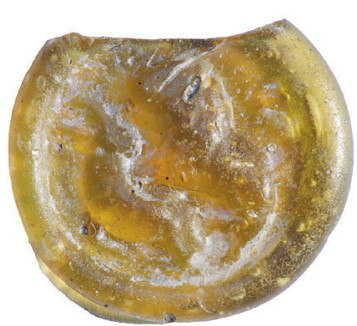

2.

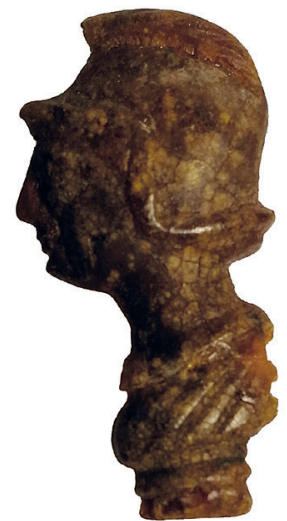

5.

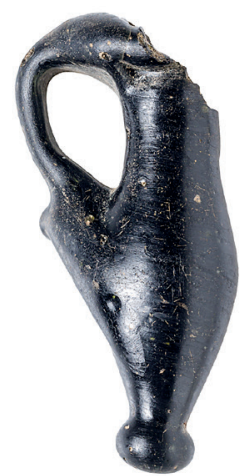

8.

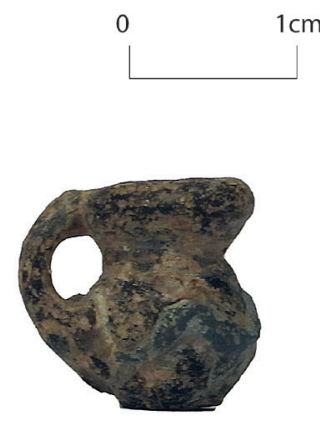

3.

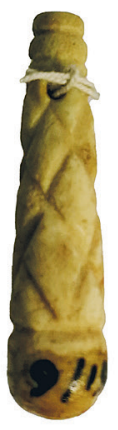

6.

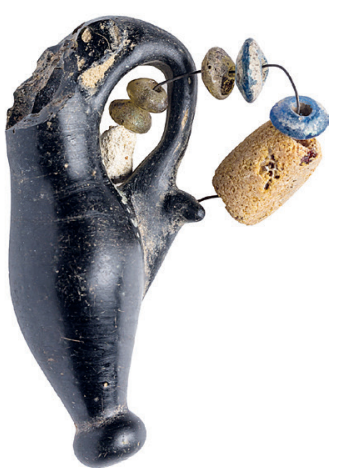

Fig. 1. Opaque black juglet pendant with openwork cage was made by applying a single turquoise zig-zag trail between the horizontal trails on the body from Brigetio

Fig. 2. An amber yellow disc pendant with the stamped depiction of a lion from Brigetio

Fig. 3. Opaque brownish juglet decorated with a bluish-green opaque trail (Museum of Fine Arts in Budapest, inv. no. 51.2487.) (Photo: Á. Bollók)

Fig. 4. Drak blue juglet pendant from the cemetery of Ságvár, Grave 131 (Hungarian National Museum, inv. no. 9.1939.13.)

Fig. 5. Head of Athena from the cemetery of Ságvár, Grave 131 (Photo: T. Szabadváry)

Fig. 6. Bone amulet in the shape of Hercules' club from the cemetery of Ságvár, Grave 131 (Photo: T. Szabadváry)

Fig. 7. Opaque black juglet pendant made from a hollow twisted glass rod decorated with an opaque white trail (Rippl-Rónai Museum, Kaposvár, inv. no. R94.111.2.)

Fig. 8-9. Opaque, black juglet amulet from the late Roman cemetery of Bogád, Grave 3 (Photo: D. Helmli) 


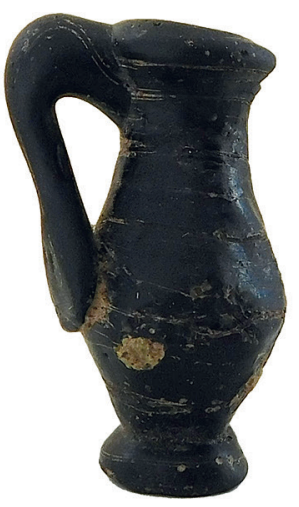

10.

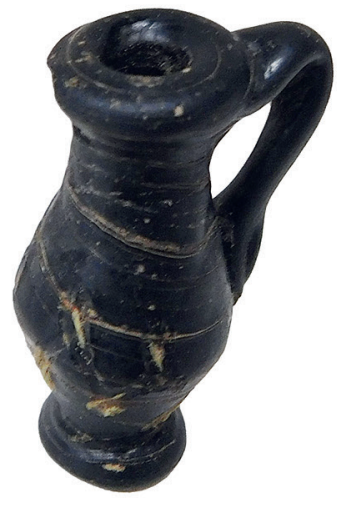

11.

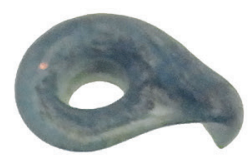

12.

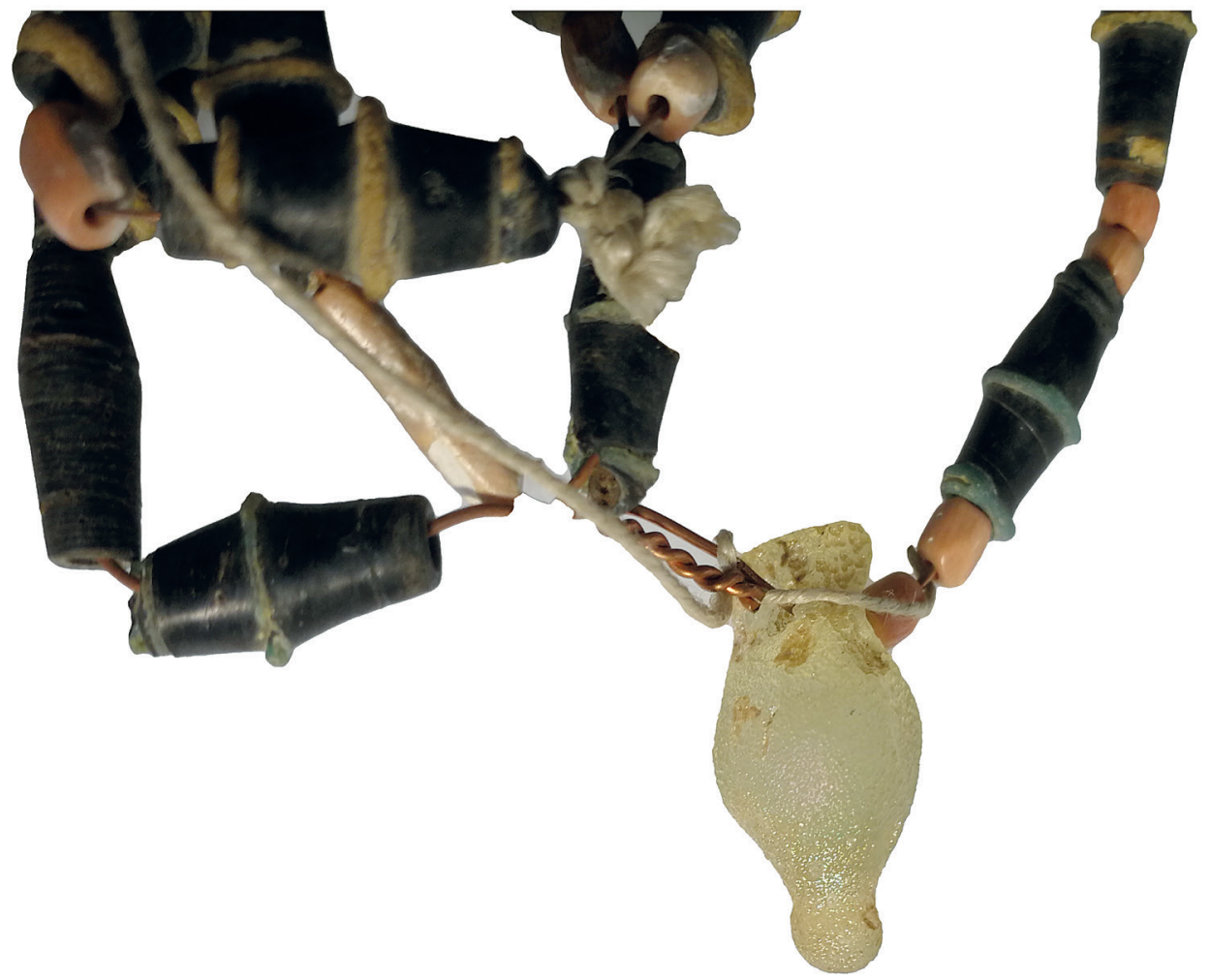

13.

Fig. 10-11: Opaque, black juglet pendant from Csongrád (Tari László Museum, Csongrád, inv. no. 88.73.4.)

Fig. 12. Ear fragment of blue juglet pendant (Hungarian National Museum, inv. Nr. 3.1921.20.

Fig. 13. Opaque, white juglet pendant from Intercisa (Hungarian National Museum, inv. Nr. 28.1908.431.) (Photo: T. Szabadváry) 
$1500 \mathrm{~m}^{2}$ was excavated by A. Sz. Burger between 1959 and $1961 .^{51}$ Grave 3, an east to west oriented brick burial, contained the interment of a child, whose grave goods included an iron knife, bone hairpins, a bronze bracelet and glass beads (an opaque white bead, an opaque brown prismatic bead, and two blue and three brown spherical beads). The black juglet amulet is modelled in the shape of a one-handled slender juglet with an applied disc for a base (H. $4.1 \mathrm{~cm}$ ).

The seventh juglet pendant was found in Hungary, although not in the former Roman province, but in the Barbaricum. It is housed in the Tari László Museum in Csongrád (inv. no. 88.73.4.; H. $3.4 \mathrm{~cm}, \mathrm{dR} .1 .1 \mathrm{~cm}, \mathrm{~dB}$. $1.1 \mathrm{~cm})$ (Fig. 10-11). The accessions register specifies the site as Csongrád, 8 Iskola Street, and that it was part of László Tari's estate. ${ }^{52}$ M. Párducz published this piece in 1968. According to his description, the pendant came to light from a female burial that was disturbed while digging a ditch. The grave goods included a coin dating from the fourth century, a silver brooch, a silver pendant, an iron knife, a necklace of glass beads and the juglet amulet. It seems likely that the latter had been strung among the beads. ${ }^{53}$ The body and rim of the opaque black one-handled juglet was made from a hollow twisted rod, while its base was applied separately. It is the simplest among the Hungarian pieces, lacking any decoration.

The eighth is fragmentary piece (Hungarian National Museum, Inv. Nr. 3.1921.20.) (Fig. 12). An ear fragment of a juglet from a blue, translucent glass. A fragmentary piece of part a necklace of glass beads comes from Intercisa.

The ninth is opaque, white juglet from Intercisa is part of a necklace from different glass beads. (Hungarian National Museum, Inv. Nr. 28.1908.431.) The shape of the juglet is stylized, solid and has no ears (Fig. 13). ${ }^{54}$

Regarding the juglet pendants from Hungary, it remains uncertain whether the piece in the Museum of Fine Arts had actually been found in Hungary, even though this seems quite likely. The other finds all have a Hungarian provenance: aside from the piece found in the Barbaricum, the other seven juglet pendants originate from Pannonia. Three exemplars were parts of grave inventories, whose other items are also known (Bogád, Csongrád and Ságvár). All three burials can be securely dated to the fourth century. Two juglet pendants were recovered from female burials, one from a child's grave. In all documented cases, the burial contained a strand of beads made of glass and other material (bone, amber, etc.), suggesting that the juglet pendants had been strung among the beads. Grave 131 of Ságvár is particularly interesting because in addition to the juglet pendant, it contained other pendants too, for example one representing an attribute of Hercules. Although the other two Pannonian pendants were single finds collected in the field, we do have information about the find circumstances. The specimen in the Klujber Collection probably originates from the Pannonia-dülö area, where the cemeteries of the military fort of Brigetio lay, and thus it was probably part of a late Roman grave inventory, similarly to the pendant in the collection of the Rippl-Rónai Museum in Kaposvár. Knowing that the finder, György Fekete, worked as a teacher in Mosdós from where late Roman graves are known, we may reasonably assume that the pendant came from a late Roman burial in Mosdós.

In the light of the above, we may assert that these pendants had often been deposited in burials. Most of the known finds originate from the late Roman province of Valeria, whose seat in Sopianae was one of the centres of Pannonian Christianity. Three of the juglet pendants come from this area. Although this in no way provides any conclusive evidence for the religious beliefs possibly associated with the juglet amulets, it must be borne in mind that countless early Christian relics and burials are known from the region. However, the fact that the juglet pendant from Ságvár was found in association with various other amulets, specifically an amulet in the shape of Hercules' club and an amulet depicting the head of Athena, raises some doubts whether juglet amulets can be linked to Christian beliefs.

Juglet pendants come in a wide variety of forms, ranging from simple undecorated pieces to finely made miniature vessels decorated with delicate trails. The pendants include both rod-formed and biconical juglets, either with marvered trail or openwork cage decoration. The juglet pendant from Ságvár is outstanding in several respects: its delicate, slender form is the exact miniature counterpart of the period's jugs, its rim was created from a separate trail, its base from a separate disc, while its neck is adorned with a spiral trail and the vessel handle was carefully

\footnotetext{
${ }^{51}$ BURGER 1962, 112.

${ }^{52}$ I am grateful to Balázs Mellár for the information on this pendant.

${ }^{53}$ PÁRDUCZ 1968, 28

${ }^{54}$ AlFÖLDI-BARKÓCZI 1957, 442-443, Abb. 94.

${ }^{55}$ Bollók 2018, 763-793. I'm grateful for Á. Bollók for sharing his advice for me.
}

Acta Archaeologica Academiae Scientiarum Hungaricae 71, 2020 
made as shown by its well-discernible lower attachment end. In contrast, most of the Pannonian juglet pendants are more simple pieces.

Despite the attractiveness of M. Stern's suggestion, there is no good reason to associate the Pannonian juglet pendants recovered from mortuary contexts with Christianity. When Stern proposed her interpretation of a possible use as pilgrim eulogia containers, there were no more than a few pieces with a secure context, and most of the pieces discussed by her were stray finds in museum collections. However, this is no longer the case and it is by now clear that juglet pendants appear at a far too early date and in far too many contexts that cannot be regarded as Christian for them to be viewed as Christian eulogia containers. The pieces from Pannonia would rather suggest that juglet pendants cannot be associated with Christian beliefs because the other grave goods in the burials from which they were recovered beliefs this association.

Moreover, the small size and form of juglet pendants makes them unsuitable for containing eulogiai, and neither would their sealing have been as easy matter. Had their intended function been to serve as containers, these miniature vessels would have doubtless been made in a form to enable this function as shown by the later, fifthsixth-century eulogia containers. In any case, eulogiai were not particularly widespread in the fourth century and objects that can be conclusively identified as pilgrim eulogiai can be generally dated to the fifth-sixth centuries. ${ }^{55}$

It is my belief that juglet pendants were worn as lucky charms for warding off evil. The Pannonian finds suggest that they were strung among the beads - made of glass and other material - of necklaces. Most juglet pendants are simple pieces of opaque black glass. It has been noted in the above that opaque black glass was made in imitation of jet, to which magical healing properties and protective powers were ascribed in Antiquity. It is quite possible that the juglet pendants were used as containers for various herbs and functioned as apotropaic amulets, whose use is attested in fourth-century Pannonia. There is nothing to suggest that the Pannonian juglet amulets recovered from mortuary contexts had been eulogia containers. In any case, the fourth century was a period characterised by a colourful diversity of traditions, from which one could draw freely when yearning for recovery from some ailment and for protection from evil.

The goal of this paper presenting the juglet pendants currently known from Hungary was to contribute to the study of the type. A systematic classification and assessment of the known pieces will no doubt enhance our knowledge of this intriguing late Roman pendant type.

A further curiosity is that we also know from other metals, such as bronze, pendants of the same shape and size as glass specimens, which can be dated to an earlier period. An interesting question is that could not specimens made of bronze be forerunners of glassware?

\section{REFERENCES}

ALFÖLDI-BARKÓCZI 1957

BARKÓCZI 1951

BARKÓCZI 1988

BARKÓCZI 1996

BARTUS 2003

BOLLÓK 2018

BURGER 1966

CSIZMADIA 1998

DÉVAI 2015

ENTWISTLE-FINNEY 2013

KELLER 1971
= M. R. AlfÖLDI-L. BARKóCZI (et al.): Intercisa. 2.: (Dunapentele). Geschichte der Stadt in der Römerzeit. ArchHung 36. Budapest 1957.

= L. BARKóCZI: Brigetio. DissPann. II.22. Budapest 1951.

= L. BARKÓCZI: Pannonische Glasfunde in Ungarn. StudArch 9. Budapest 1988.

= L. BARKÓCZI: Antike Gläser. MAEFH 5. BiblArch 19. Roma 1996.

= D. BARTUS: Római kori csontfaragványok a komáromi Klapka György Múzeumban [Roman bone carvings from the Klapka György Museum, Komárom]. [Manuscript.] Budapest 2003.

= Á. BollóK: "Portable sanctity" brought to the afterlife: pilgrim eulogiai as grave goods in the Late Antique Eastern Mediterranean. In: Across the Mediterranean - Along the Nile. Studies in Egyptology, Nubiology and Late Antiquity Dedicated to László Török on the Occasion of His 75th Birthday. Eds.: T. A. Bács, Á. Bollók, T. Vida. Budapest 2018, 763-804.

= A. Sz. BuRger: The late Roman cemetery at Ságvár. ActaArchHung 18 (1966) 99-224

= G. CsizmadiA: A kaposvári Rippl-Rónai Múzeum római kori üvegleletei [Roman glass finds from the Rippl-Rónai Museum, Kaposvár]. SMK 13 (1998) 91-111.

$=$ K. DÉvaI: New data to the products of the glass workshop of Brigetio. In: Studia archaeologica Nicolae Szabó LXXV annos nato dedicata. Ed.: L. Borhy, K. Tankó, K. Dévai. Budapest 2015, $105-112$.

= C. Entwistle-P. C. Finney: Late Antique Glass Pendants in the British Museum. London 2013.

= E. KELLER: Die spätrömischen Grabfunde in Südbayern. [Diss.] Veröffentlichungen/Bayerische Akademie der Wissenschaften München, Kommission zur Archäologischen Erforschung des Spätrömischen Raetien 8. Münchner Beiträge zur Vor- und Frühgeschichte 14. München 1971.

Acta Archaeologica Academiae Scientiarum Hungaricae 71, 2020 
LOESCHKE 1925

NÉMETH 2018

PÁRDUCZ 1968

RIHA 1990

SCHMIDT 2000

SCHUlZE 1978

SPAER 1991

STERN 1977

STERN 1995

STREN 2001

WHITEHOUSE 2003

WILD 1981
= L. LOESCHKE: Frühchristliche Werkstatt für Glasschmuck. In: Trierer Heimatbuch. Festschrift zur rheinischen Jahrtausendfeier 1925. Hrsg.: Gesellschaft für Nützliche Forschungen zu Trier. Trier $1925,337$.

= P. G. NÉMETH: Somogy megye római kori temetői [Roman cemeteries of Somogy County]. A Kaposvári Rippl-Rónai Múzeum Közleményei 5 (2018) 95-126.

= M. PÁRDUCZ: Újabb hun kori leletek Csongrád megyében [Other Hun finds in Csongrád County]. MFMÉ 1968, 27-33.

= E. RIHA: Die römische Schmuck aus Augst und Kaiseraugst. Forschungen in Augst 10. Augst 1990.

=W. SchmidT: Spätantike Gräberfelder in den Nordprovinzen des römischen Reiches und das Aufkommen christlichen Bestattungsbrauchtums. Tricciana (Ságvár) in der Provinz Valeria. SJ 50 (2000) 290-439.

= M. SCHULZE: Zur Interpretation spätkaserzeitlichen Glasperlen. AKorr 8 (1978) 51-68.

= M. SPAER: Ancient Glass in the Israel Museum: Beads and Other Small Objects. Catalogue/Israel Museum, Jerusalem 447. Jerusalem 1991.

= E. M. Stern: Ancient Glass at the Fondation Custodia (Collection Frits Lugt) Paris. Archaeologica Traiectina 12. Groningen 1977.

= E. M. STERn: Roman Mould-Blown Glass. The first through sixth centuries. [Toledo Museum of Art.] Roma 1995.

= E. M. STERN: Römisches, byzantinisches und frühmittelalterliches Glas. 10 v. Chr.-700 n. Chr. Sammlung Ernesto Wolf. [Ostfildern] 2001.

= D. WhitehousE: Roman Glass in the Corning Museum of Glass. 3. Catalog series/Corning Museum of Glass. Corning 2003.

= R. A. WILD: Water in the Cultic Worship of Isis und Sarapis. EPRO 87. Leiden 1981

Open Access. This is an open-access article distributed under the terms of the Creative Commons Attribution 4.0 International License (https:// creativecommons.org/licenses/by/4.0), which permits unrestricted use, distribution, and reproduction in any medium, provided the original author and source are credited, a link to the CC License is provided, and changes - if any - are indicated. (SID_1)

Acta Archaeologica Academiae Scientiarum Hungaricae 71, 2020 